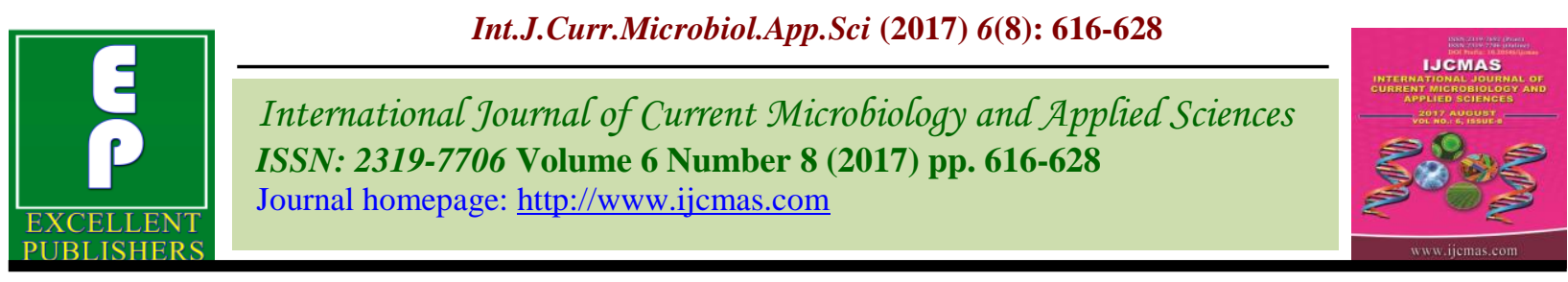

Review Article

https://doi.org/10.20546/ijcmas.2017.608.079

\title{
Detection and Management of Abiotic Stresses in Wheat Using Remote Sensing Techniques
}

\author{
Sukhjeet Kaur*, Som Pal Singh and P.K. Kingra \\ School of Climate Change and Agricultural Meteorology, PAU, Ludhiana, India \\ *Corresponding author
}

\author{
A B S T R A C T
}

Keywords

Thermal stress, Nutrient stress, Remote sensing, Spectral vegetation indices management strategies.

\section{Article Info}

Accepted:

04 June 2017

Available Online:

10 August 2017
Different aspects of climate change, such as higher atmospheric $\mathrm{CO}_{2}$ concentration, increased temperature and changed rainfall patterns have different effects on crop yields. In combination, these effects can either increase or decrease crop production as the net effect of climate change on crop yield depends on the interactions between these factors. Among all changes, temperature plays a dominant role for wheat production in India. The high temperature stress at reproductive phase of crop results in poor yield due to reduced number of grains per spike and shriveled grains with poor quality. Along with thermal stress, the continuous availability of nutrients to wheat during various phases of its growth and development is important factor which influences the grain yield. So suitable production strategies for obtaining higher yield under stress conditions need to be developed for detection of these stresses at early stages of crop growth. Among these strategies, remote sensing techniques provide a platform for which plant stress and growth response can be evaluated. Variation in spectral reflectance under different type of stresses in the form of spectral vegetation indices allows us to develop suitable strategies for reducing these stresses and helps in maximizing the wheat yield. The impact of these stresses on wheat productivity can be minimized by adoption of various agronomic management practices as time of sowing, alternative method of planting, nutrient management, mulching, seed priming, foliar spray of salts and foliar spray of micronutrients to mitigate the high temperature effect on the productivity of wheat.

\section{Introduction}

Wheat is a photo-insensitive and thermosensitive long day plant. It requires cool climate during the early part of its growth. Temperature plays a dominant role for wheat production in India. Both the start and end of wheat crop season are limited by temperature regimes. Within the growing season itself, warmer temperature shortens the vegetative crop duration. Wheat grain yield and quality are also influenced by temperature regimes during different phases of crop growth. High temperature during early vegetative phase results in sparse tillering, poor vegetative growth and early heading; and during grain filling phase it leads to forced maturity (Reddy 2006). The IPCC (2014) has reported the globally averaged combined land and ocean surface temperature of $0.85^{\circ} \mathrm{C}$ over the period 1880 to 2012. The warming is more pronounced over land areas with a maximum increase over northern India. Increased concentrations of greenhouse gases and warming will have serious consequences like increased evaporation, uncertainty of 
monsoon rainfall, increased frequency of extreme events like floods, droughts, heat waves etc. All these events have profound impact on crop yields due to increased abiotic and biotic stresses (Reddy and Hodges, 2000).

Growth and development of wheat is adversely affected by environmental stresses like high temperature, soil moisture deficit, nutrient stress, low light intensity, etc. Temperature and nutrient play important role in growth, development and yield of wheat. Extremely high and low temperature as well as higher or lower dose of nutrients has a detrimental effect on crop growth, development and yield. Estimates indicate that in India alone around 13.5 million hectares of wheat is under heat stress (Joshi et al., 2007). The high temperature stress at reproductive phase of crop results in poor yield due to reduced number of grains per spike and shriveled grains with poor quality (Sharma et al., 2007). Along with thermal stress, the continuous availability of nutrients to wheat during various phases of its growth and development is important factor which influence the grain quality and yield (Kumari et al., 2000). Among the several nutrients, nitrogen is the most important responsible to a great extent for the higher yields under intensive agriculture. Application of nitrogen enhances not only biomass production but also yield and yield components (Latiri-Souki et al., 1998).

Therefore, it becomes imperative to develop suitable production practices for obtaining higher yield under thermal and nutrient stress conditions. In the effort of developing sustainable production strategies, remote sensing has been commonly considered as an effective technique for non-destructive monitoring of plant growth viz. for the detection of many environmental stresses which limit plant growth like temperature stress, nutrient deficiencies, diseases, water stress, wind damage etc and allow us to develop suitable strategies for reducing the effect of different stresses in wheat for maximizing the yield. Since reflectance of crops and soils differs in the visual and near infrared wavelengths under both stressed as well as unstressed conditions, there is potential for using reflection measurements at different wavelengths to distinguish yield as well as quality differences in wheat crop when observed under thermal and nutrient stresses. Keeping this in view, the relevant literature depicting the effect of heat and nutrient stresses in wheat, the significance of remote sensing for detecting these stresses and suitable strategies for their management has been consulted and presented in the manuscript.

\section{Effect of thermal stress on growth and yield of wheat}

The temperature rise is likely to be much higher during the winter (Rabi) rather than in the rainy (Kharif) season. It is projected that by the end of the 21 st century, rainfall over India will increase by $10-12$ per cent and the mean annual temperature by $3-5^{\circ} \mathrm{C}$. The warming is more pronounced over land areas with a maximum increase over northern India. Perry and Swaminathan (1992) reported that an increase of $0.5^{\circ} \mathrm{C}$ temperature resulted in decrease in the duration of wheat crop by seven days, which reduced the yield by 0.5 tonnes per hectare in North India. High temperature enhanced the plant growth, flowering and maturation, thus the number of days to booting, heading, anthesis and maturity of wheat were significantly decreased (Rahman et al., 2009). The stress was experienced either throughout crop growth period or at one of the three growth phase's viz., seedling to ear initiation, ear initiation to flowering and flowering to maturity. The warmer temperature hasten crop development, shortens the growth period 
(Zacharias et al., 2010 and Hossain et al., 2012). A significant inverse correlation was observed between mean seasonal ambient temperatures with culm length, spike length, duration from heading to maturation and thousand-grain weights (Nishio et al., 2013). Heat stress modified the early dough stage and maturity, shortened the kernel desiccation period and caused grain yield loss. Plants subjected to stress at the early growth stages had higher grain yields than the nonearly-stressed plants when stress reoccurred at anthesis (Zhang et al., 2013).

Heat stress reduces plant photosynthetic capacity through metabolic limitations and oxidative damage to chloroplasts, with concomitant reductions in dry matter accumulation and grain yield (Farooq et al., 2011). The rate of decrease in grain yield was more for higher temperatures rise in contrast to lower temperatures and the rate of increase in grain and biomass yield was more for higher $\mathrm{CO}_{2}$ concentration with lower levels. On an average, there was $8 \%$ decrease in wheat grain and biomass yield per $1{ }^{\circ} \mathrm{C}$ increase in temperature (Mohanty et al., 2015). The grain yield decreased from 0.7 to 3.3 percent when temperature increased by $1{ }^{\circ} \mathrm{Cduring}$ second fortnight of February, 2.1 to 3.2 percent during first fortnight of March, 1.24 to 3.4 percent during second fortnight of March and 0.38 percent during first week of April (Prabhjyot-Kaur and Hundal, 2010). With the increase in temperature (maximum and minimum) during grain filling period, all the yield components of wheat were reduced in mean values ranging from 4.77 to $10.05 \%$ (Singh et al., 2006).

Because of exposure to high temperature during grain filling and maturity under late sown conditions, the development of plant organs and transfer from source to sink were remarkably affected with delayed planting, which was reflected by overall shortening of plant height, reduction in number of internodes, days to heading, days to maturity and grain filling period and ultimately in the reduction of yield and yield components. Refay (2011) also reported that delayed sowing was associated with substantial loss in grain yield estimated as 7.98 per cent as compared to early sowing. The highest values of spike weight, grain yield and dry biological yield were obtained when the crop was sown in November. Similar results were also reported by Mukherjee (2012), Andarzian et al., (2015), Fayed et al., (2015) and Meena et al., (2015). The protein content of the genotypes was higher in late condition, possibly due to low grain weight (Sial et al., 2005). Sowing dates severely influenced protein and carbohydrate contents in subsequent grains of wheat crop (Table 1). Wheat crop sown from the seeds obtained from the crop previously sown at November 10 and 25 showed better grain protein and carbohydrate content as compared to December 10 and 25 (Hussain et al., 2015). The protein content and bread quality are improved by delayed sowing due to synthesis of heat shock proteins under such conditions (Abdullah et al., 2007 and Munsif et al., 2015). Best chapati quality was obtained in mid and late sowings because protein content was higher in delayed sown crop (Abdullah et al., 2007 and Eslami et al., (2014).

\section{Effect of nutrient stress on growth and yield of wheat}

The continuous availability of nutrients to wheat during various phases of its growth and development is important factor which influence the grain quality and yield of wheat (Kumari et al., 2000). Increased crop growth due to nitrogen fertilization is attributed to increased leaf-area index (LAI) and radiation interception (Caviglia and Sadras, 2001).The nutrient content in grain and straw increased with delay in sowing of wheat whereas, 
uptake of these nutrients decreased as the sowing of wheat gets delayed (Kumar et al., 1998). The $\mathrm{N}$ use efficiency was also greater in optimum and early sown crop compared to late sown crop.

Nutrient stress has a significant impact on growth and yield of wheat. It's yield and quality are adversely affected due to wheat stress but significantly improved under increase in dose of fertilizers. The number of productive tillers per $\mathrm{m}^{2}, 1000$-grain weight and grain yield of wheat increased with the application of $150 \mathrm{~kg} \mathrm{~N} \mathrm{ha}{ }^{-1}$ (Ali et al., 2003).Maximum plant height, total number of plants $/ \mathrm{m}^{2}$, number of spikes $/ \mathrm{m}^{2}$, spike weight, biological yield and grain protein content were observed at $200 \mathrm{~kg} \mathrm{~N} / \mathrm{ha}$ (Hussain et al., 2006 and Iqbal et al., 2012). Grain yield increase was mainly due to increase in the number of effective tillers (Abad et al., 2005). The rate and time of $\mathrm{N}$ application had significant effect on grain yield (Haile et al., 2012). There was $4.14 \%$ increase in grain yield when $\mathrm{N}$ was applied as $45 \%$ of recommended $\mathrm{N}(150 \mathrm{~kg})$ at sowing followed by $50 \%$ at first irrigation and $5 \%$ as foliar application at the rate of $3 \%$ concentration over recommended schedule (Kaur et al., 2010). The combined application of plant growth regulator (PGR) treatments and higher nitrogen rates reduced the plant height and this reduction played an important role in the increase of the grain yield in wheat, via the alteration of dry matter partitioning into the spikes (Shekoofai and Emami, 2008) (Table 2). The grain yield, nitrogen absorption, and nitrogen harvest index were increased with increasing nitrogen fertilization level when the nitrogen application rate was $0-150 \mathrm{~kg} \mathrm{~N}$ $\mathrm{x} \mathrm{hm}{ }^{-2}$, but not further increased significantly (Li et al., 2013). Similar findings were also observed by Akram et al., (2014) and Mandic et al., (2015). Nitrogen application improved grain protein and reduced phosphorous percentage (Warraich et al., 2002) (Table 3).
Nitrogen rate increased hectoliter weight and grain protein, but decreased NUE (Campillo et al., 2010). The dose of $200 \mathrm{~kg} \mathrm{~N} / \mathrm{ha}$, compared to dose of $150 \mathrm{Kg} \mathrm{N} / \mathrm{ha}$, significantly increased the protein content (Maqsood et al., 2000; Cui et al., 2005 and Hussain et al., 2006). The reduction of $\mathrm{N}$ reduced grain yield, agronomic NUE, grain protein content, grain $\mathrm{N}$ content and bread volume but caused increasing of thousand kernel weight (Khalilzadeh et al., 2011). Split application of $\mathrm{N}$ resulted in superior quality attributes than when the entire $\mathrm{N}$ was applied at once. The sensitivity of rate and time of $\mathrm{N}$ application was found to be greater in the wheat quality attributes than the grain yield and yield components (Ooro et al., 2011 and Moraes et al., 2013). The simultaneous increase was observed in the quality and yield with the increase of nitrogen fertilizer in winter wheat when the amount of nitrogen fertilizer was in the range of 0 and 225 $\mathrm{kg} / \mathrm{hm}^{2}$; but once the amount of nitrogen fertilizer reached $300 \mathrm{~kg} / \mathrm{hm}^{2}$, the winter wheat showed the best quality and decline both in the percentage of weight gain in grain filling stage to kernels and the kernels yield (Liu and Shahi 2013) (Table 4).

\section{Diagnosis of thermal stress using vegetation indices}

The use of thermal remote sensing, especially when combined with spectral reflectance or even fluorescence measurement, is becoming a powerful and increasingly-used tool to diagnose and monitor the effects of heat and moisture stress on plants (Jones 2009). The remotely-sensed infrared crop water stress index (CWSI) provided a useful tool for the evaluation of crop water status especially that of winter wheat and could be useful for irrigation scheduling. The relationship was developed between canopyair temperature difference and vapour pressure deficit for no stress condition of wheat crop (baseline equations), which was 
used to quantify crop water stress index (CWSI) to schedule irrigation in winter wheat (Triticum aestivum L.) (Gonita and Tiwari 2008). Chlorophyll fluorescence and chlorophyll content were reduced and chloroplast ultra-structure was disrupted by heat stress and the effect was exacerbated by low supplies of $\mathrm{Zn}$ (Peck and McDonald 2010). Camp et al., (1982) evaluated the changes in photosynthetic enzymes and photochemical activities in vegetative wheat (Triticum aestivum L.) leaves during senescence. Identification of appropriate wavelengths for monitoring changes in chlorophyll content has focused on studying the absorption coefficient. The absorption coefficient describes the incident light in the green $(\sim 550 \mathrm{~nm})$ and red edge $(\sim 700 \mathrm{~nm})$ spectra has been found to have a very low absorption coefficient as compared to light in the blue $(\sim 450 \mathrm{~nm})$ and red $(\sim 650 \mathrm{~nm})$ spectra. Gitelson et al., (2003) also demonstrated the relationship between leaf chlorophyll content and spectral reflectance. A simple and integrated way to measure staygreen in large sets of germplasm is using a Green-Seeker to measure NDVI during the grain-filling stage in wheat plots. NDVI has been related to temperature stress, nitrogen status; chlorophyll content, green leaf biomass, and grain yield (Shanahan et al., 2003). The cumulative effects to improve stress adaptation may be achieved by introgressing low canopy temperature and stay-green expression traits into new wheat lines (Lopes et al., 2012). High temperature during anthesis and grain development stages coupled with sharp irradiance, low humidity and moisture deficit, resulting in adverse effect on different vital activities and finally the yield and yield attributes of the crop (Srivastava et al., 2012).

Table.1 Sowing date effect for the quality characters

\begin{tabular}{|l|c|c|c|c|c|c|}
\hline Quality charactersitcs & $\mathbf{2 5}^{\text {th }}$ Oct. & $\mathbf{1 0}^{\text {th }}$ Nov. & $\mathbf{2 5}^{\text {th }}$ Nov. & $\mathbf{1 0}^{\text {th }}$ Dec. & $\mathbf{2 5}^{\text {th }}$ Dec. & $\mathbf{1 0}^{\text {th }}$ Jan. \\
\hline Protein content & 11.94 & 12.27 & 12.49 & 12.62 & 12.57 & 12.92 \\
\hline Flour yield & 71.31 & 70.21 & 68.67 & 67.24 & 67.24 & 64.40 \\
\hline Bread quality & 69.75 & 70.61 & 70.95 & 71.65 & 71.71 & 72.56 \\
\hline Chapatti quality & $\begin{array}{c}\text { Fair to fairly } \\
\text { good }\end{array}$ & $\begin{array}{c}\text { Fairly good } \\
\text { to good }\end{array}$ & Good & Good & Good & $\begin{array}{c}\text { Fairly good } \\
\text { to good }\end{array}$ \\
\hline
\end{tabular}

(Source: Abdullah et al., 2007)

Table.2 Effect of $\mathrm{N}$ rates on grain yield of wheat

\begin{tabular}{|c|c|c|}
\hline \multirow{2}{*}{ N levels $\left(\mathbf{k g ~ h a}^{-\mathbf{1}}\right)$} & \multicolumn{2}{|c|}{ Grain yield $\left(\mathrm{kg} \mathrm{ha}^{\mathbf{- 1}}\right)$} \\
\cline { 2 - 3 } & $\mathbf{2 0 0 0 - 0 1}$ & $\mathbf{2 0 0 1 - 0 2}$ \\
\hline 84 & 2940 & 3600 \\
\hline 128 & 4090 & 4770 \\
\hline 150 & 4330 & 5160 \\
\hline 175 & 3890 & 4920 \\
\hline 200 & 3250 & 4730 \\
\hline LSD $(<0.05)$ & 38.81 & 6.85 \\
\hline
\end{tabular}

(Source: Ali et al., 2003)

Table.3 Effect of nutrient management on growth parameters of wheat varieties

\begin{tabular}{|c|c|c|c|c|}
\hline Treatment & $\begin{array}{c}\text { LAI } \\
(90 \text { DAS })\end{array}$ & $\begin{array}{l}\text { Crop Growth rate } \\
\text { at }(60-90 \text { DAS }) \\
\left(\mathrm{g} / \mathrm{m}^{2} / \text { day }\right)\end{array}$ & $\begin{array}{l}\text { Relative Growth } \\
\text { rate at (60-90 DAS) } \\
\text { (mg/g/day) }\end{array}$ & $\begin{array}{l}\text { Crop Growth rate at } \\
(60-90 \text { DAS })\left(\mathrm{g} / \mathrm{dm}^{2}\right. \\
\text { leaf area/day) }\end{array}$ \\
\hline $100 \% \mathrm{RDF}$ & 5.39 & 10.72 & 41.57 & 3.17 \\
\hline $50 \% \mathrm{RDF}+50 \% \mathrm{RDN}$ & 5.95 & 12.00 & 42.81 & 3.27 \\
\hline SEm & 0.05 & 0.14 & 0.43 & 0.03 \\
\hline $\mathrm{CD}(\mathrm{P}=0.05)$ & 0.15 & 0.46 & 1.36 & 0.11 \\
\hline
\end{tabular}

$\mathrm{RDF}=$ Recommended dose of fertilizer RDN $=$ Recommended dose of nitrogen. 
Table.4 Interaction effects of nitrogen and compost on wheat grain yield $\left(\mathrm{kg} \mathrm{ha}^{-1}\right)$

\begin{tabular}{|l|c|c|c|c|}
\hline \multirow{2}{*}{ Nitrogen (Kg/ha) } & \multicolumn{4}{|c|}{ Compost (Mg/ha) } \\
\cline { 2 - 5 } & $\mathbf{0}$ & $\mathbf{3 0}$ & $\mathbf{6 0}$ & Mean \\
\hline $\mathbf{0}$ & 1274.19 & 3600.90 & 3312.65 & 2720.20 \\
\hline $\mathbf{8 0}$ & 2893.58 & 4206.67 & 5274.42 & 4124.80 \\
\hline $\mathbf{1 6 0}$ & 3439.00 & 7546.19 & 6548.55 & 5844.59 \\
\hline $\mathbf{2 4 0}$ & 4507.00 & 6089.94 & 5307.09 & 5301.00 \\
\hline Mean & 3021.70 & 5110.60 & 5360.90 & \\
\hline
\end{tabular}

(Source: Abedi et al., 2010)

Fig.1 Spectral vegetation indices at different N-levels and phenological stages of wheat crop

Normalised Difference Vegetation Index (NDVI)

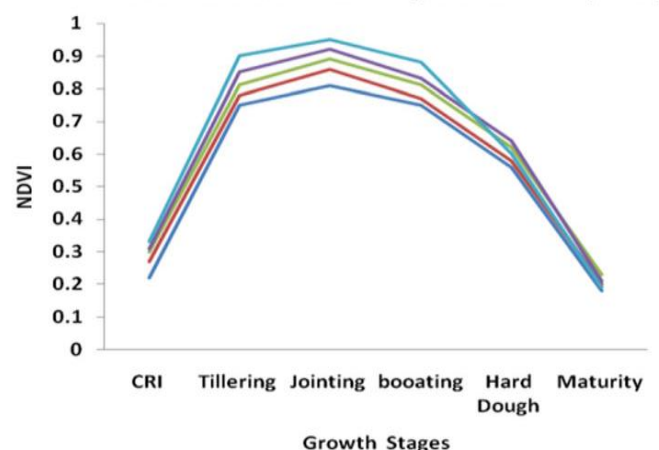

Growth Stages

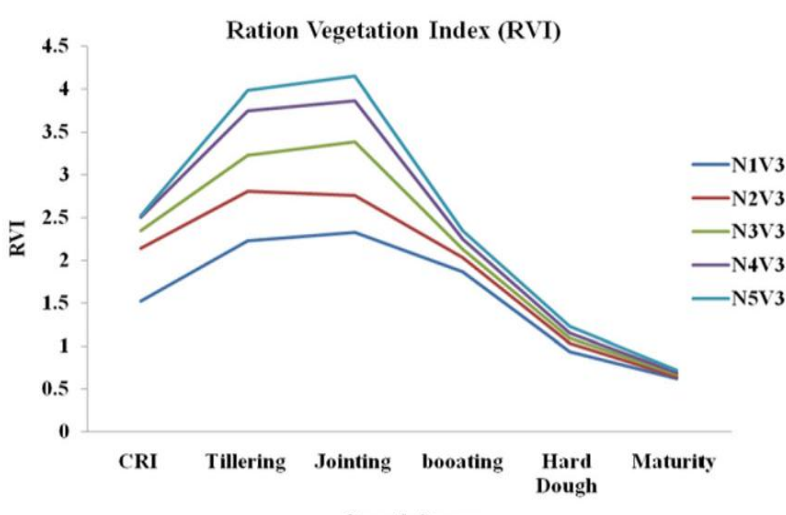

Growth Stages

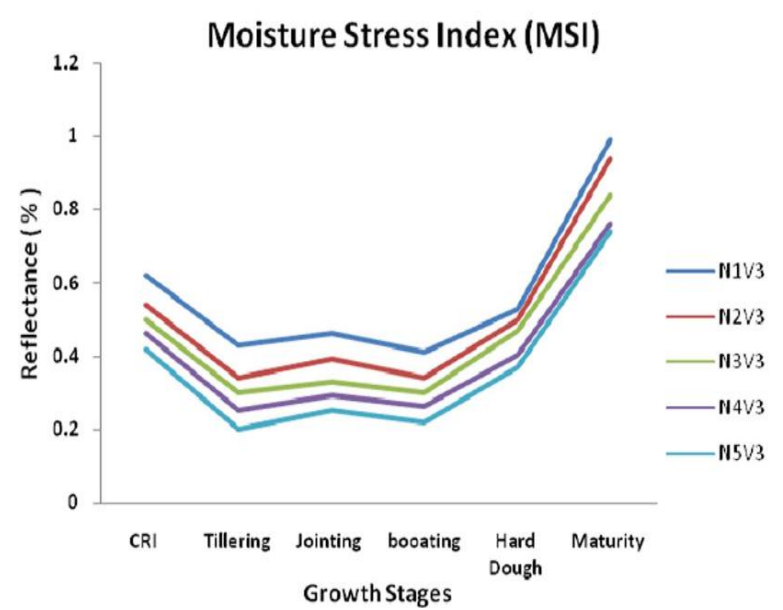

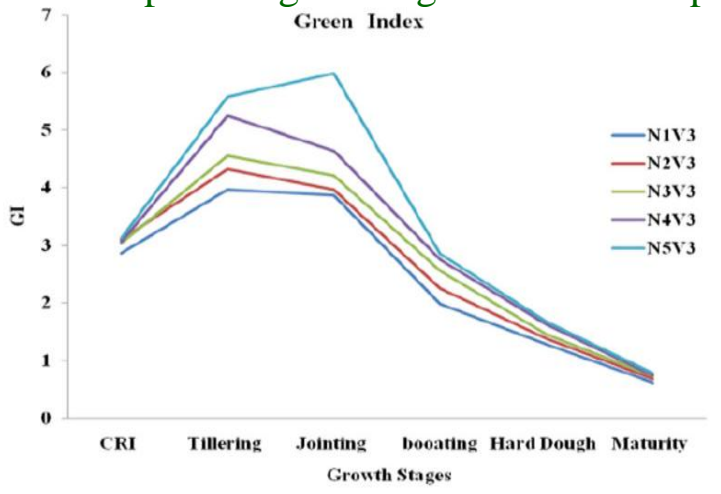

Leaf Chlorophyll Index (LCI)

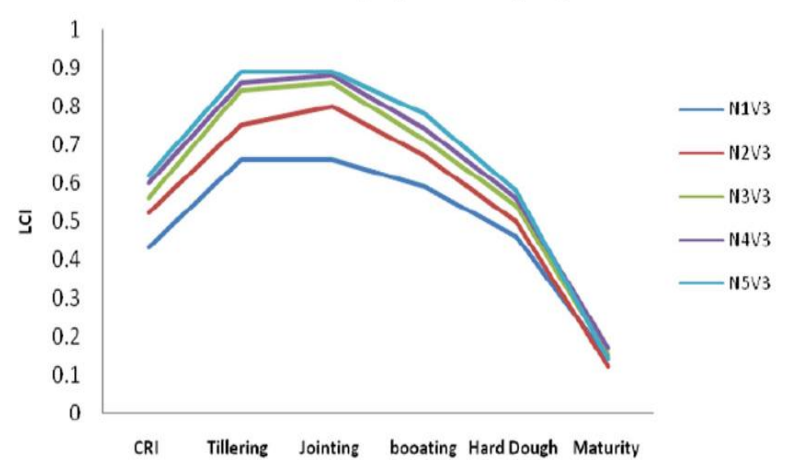

Plant Senicence Reflectance Index (PSRI)

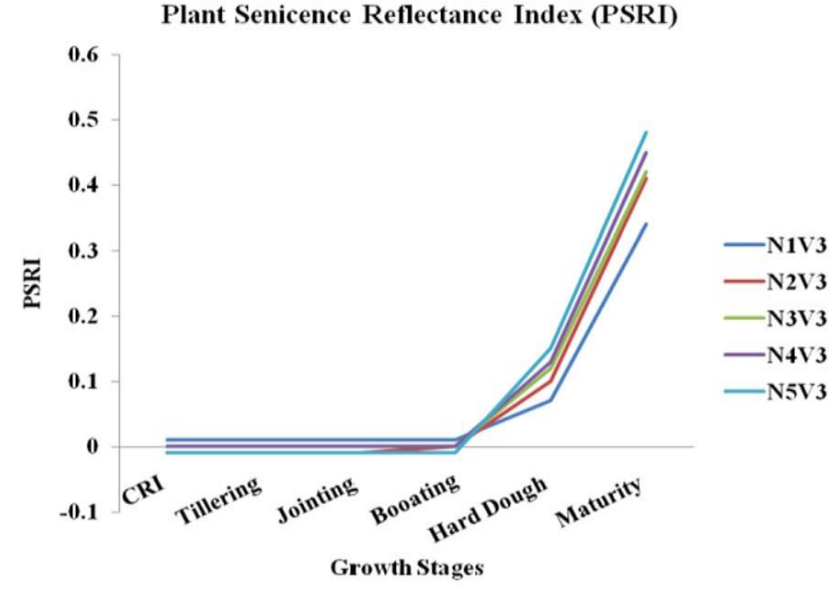

(Source: Kaur et al., 2015) 
Fig.2 Effect of agronomic practices on grain yield of wheat

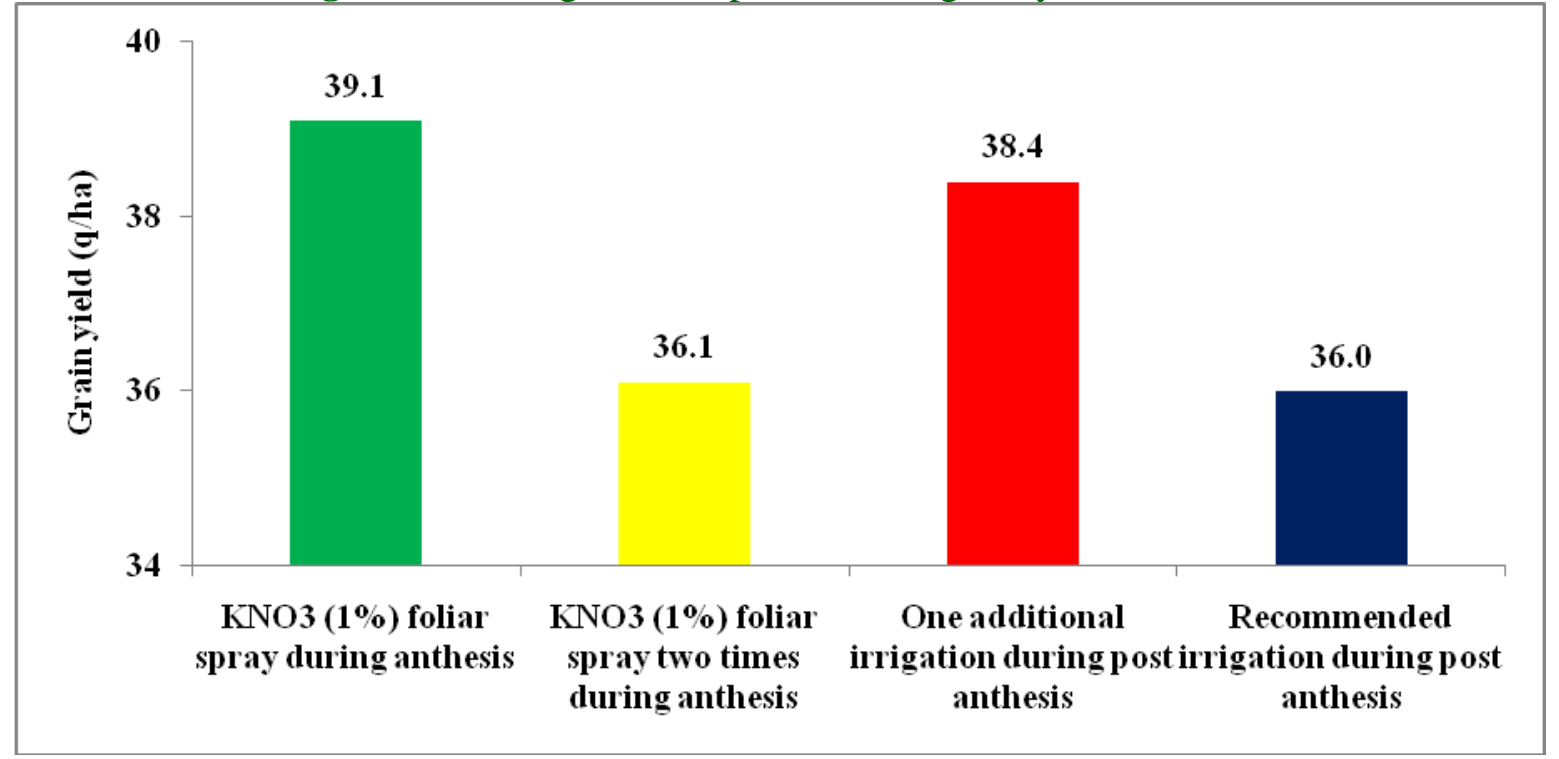

(Source: Singh, 2010)

Diagnosis of nutrient stress using vegetation indices

Aerial photography can be used to detect several factors including diseases, insect damage and $\mathrm{N}$ deficiency (Blackmer et al., 1996). Remote sensing imagery can be a better and quicker method compared to traditional method for managing nitrogen efficiently (Daughtry et al., 2000). The remote sensing technology has vital potential for the assessment of crop growth monitoring and stress detection. Infrared Red reflectance ratio and NDVI were found highly correlated with LAI and final yield, establishing the role of remote sensing for predicting grain yield. The different temporal spectral response under fertilized and nutrient deficient plots confirmed that spectral parameters can be used for detecting nutrient stress in wheat, maize, sunflower and possibly in other crops (Mahey et al., 1991). These relationships provided a method to optimize $\mathrm{N}$ rates at most critical time for achieving higher NUE (Scharf et al., 1993; Serrano et al., 2000 and Broge and Mortensen 2002). Blackmer and Schepers (1995) proposed a system for N application to corn based on photometric sensors mounted on the applicator machine. They showed that corn canopy reflectance changed with $\mathrm{N}$ rate within hybrids, and the yield was correlated with the reflected light. Aerial photographs were used to show areas across the field that did not have sufficient $\mathrm{N}$. The machine read canopy colors directly and applied the appropriate $\mathrm{N}$ rate based on the canopy color of the control (well fertilized) plots. Greenness normalized difference vegetation index (GNDVI) was significantly correlated with nitrogen content of plants. Vegetation index (VI) used in the study, whether from satellite or aircraft correlated well with preseason $\mathrm{N}$ and plant tissue analysis, but had lower correlation with protein (Wright 2003).

Remote sensing in the form of aerial color infrared (CIR) photography can be a useful tool for in-season $\mathrm{N}$ management in winter wheat (Sripada et al., 2007). The absorption band depth (ABD) normalized to the area of absorption feature (NBD) at $670 \mathrm{~nm}$ (NBD670) was the most reliable indicator for winter wheat canopy $\mathrm{N}$ status assessment (Chunjiangzhao et al., 2012). Leaf color index (LCI) was the only index which was 
correlated better, with all the plant growth parameters and yield at booting stage of the wheat crop (Kaur et al., 2015).

\section{Management of thermal stress}

The management practices to mitigate the impact of high temperature on wheat involved different techniques (Singh et al., 2011). The effect of increasing temperature during grain filling stage of wheat causes substantial reduction in grain yield. Timely sowing of wheat crop generally gives higher yield as compared to late sown crop. Late sown wheat crop faces high temperature stress during ripening phase. Adjustment in sowing time is one of the most important agronomic strategies to counteract the adverse effect of temperature stress (Kajla et al., 2015). Planting of wheat with zero tillage, bed planting and conventional tillage with mulching produced higher grain yield than conventional tillage. Organic mulches provided better soil water status and improved plant canopy in terms of biomass, root growth, leaf area index and grain yield, which subsequently resulted in higher water and nitrogen uptake and their use efficiencies. The foliar spray of $\mathrm{KNO}_{3}(0.5 \%)$ at 50 percent flowering stage, 1.0 per cent $\mathrm{KNO}_{3}$ during anthesis stage, $2.5 \mathrm{mM}$ of arginine, spray of zinc, extra irrigation water during grain filling stage, use of potassium fertilizers with municipal waste water increased the productivity of wheat under high temperature conditions. The higher grain and straw yield of wheat was obtained by spraying 0.5 per cent $\mathrm{KNO}_{3}$ at 50 per cent flowering stage of the crop (Das and Sarkar 1981) (Fig. 2).

Both $\mathrm{K}+$ and $\mathrm{Ca}^{2+}$ gave beneficial effect on grain filling and yield of wheat when applied as foliar spray at 50 per cent flowering stage of the crop (Sarkar and Tripathy, 1994). One of the reasons of reduction of crop yield is insufficient supply of micronutrients. Zinc is one of those micronutrients which have an important role in metabolic activities of the most plants (Shahramlack et al., 2011). On the other hand, its mobility is low under drought stress conditions, so this element can be sprayed to increase its intake in the plant. Inorganic $\left(\mathrm{ZnO}, \mathrm{ZnSO}^{4}\right)$ and chelated sources of $\mathrm{Zn}$ (ZnEDTA, glycine-chelated Biomin $\mathrm{Zn}$ ) applied foliarly provided sufficient $\mathrm{Zn}$ for vigorous growth (Haslett et al., 2001). Foliar application of arginine with 2.5 and $5.0 \mathrm{mM}$ on normal or delayed sowing wheat exhibited significant increment in yield and its components in comparison to untreated plants. The magnitude of increments was much more pronounced in response to 2.5 $\mathrm{mM}$ of arginine which induced 19.2, 20.5 and 25.5 per cent increases in economic yield per feddan at normally, 30 and 60 days delay, respectively (Hozayan and Monem, 2011).

\section{Management of nutrient stress}

The appropriate management of soil water, oxygen fertilization, and wellbalanced nutrients supply significantly enhance $\mathrm{N}$ uptake and utilization efficiencies of corn and wheat, and minimize $\mathrm{N}$ loss (Guodongliu et al., 2012). Application of 50\% RDF (recommended dose of fertilizer) $+50 \%$ RDN (recommended dose of nitrogen) through FYM gave significantly higher number of tillers $/ \mathrm{m}^{2}$, spike length, number of spikelets/spike, grains/spike, 1,000-grain weight and grain yield. Application of $100 \%$ recommended dose of fertilizer (RDF) in wheat, vegetable cowpea, mungbean, maize and potato gave significantly highest yield, followed by $50 \% \mathrm{RDF}+50 \% \mathrm{RDN}$ through FYM and $50 \%$ RDF $+25 \%$ RDN through FYM + biofertilizers (Singh et al., 2015). To elucidate the most effective and economical method of $\mathrm{Zn}$ application for wheat [Triticum aestivum (L.) emend. Fiori \& Paol.] Yield improvement in partially reclaimed sodic soils, all the $\mathrm{Zn}$ application methods, 
increased the plant height, tillers/plant, grains/spike, spike length, test weight, grain yield, straw yield and nutrient uptake over the control (no Zn). Foliar spray of $\mathrm{Zn}$ sulphate (5 $\mathrm{kg} / \mathrm{ha}$ hepta hydrate) resulted in $26 \%$ higher grain yield than the control. Foliar spray of 5 $\mathrm{kg} / \mathrm{ha} \mathrm{ZnSHH}$ with $2 \%$ urea in 1,000 litres water at 25 and 50 days after sowing was most economical (Mauriya et al., 2015). Application of $6 \mathrm{Kg} \mathrm{Zn} / \mathrm{ha}$ resulted in $8.8 \%$ higher grain yield $(5.22 \mathrm{t} / \mathrm{ha})$ than yield obtained in the control (4.80 t/ha) (Singh et al., 2015) (Fig. 1).

In conclusion, Wheat growth, yield and quality are adversely effected under thermal and nutrient stresses, which can lead to severe impacts under changing climatic scenarios. Remote sensing technology can be used successfully for selection of different types of stresses in wheat. Various vegetation indices viz. RI, NDVI, GNDVI, and CWSI etc. can be used efficiently for detection of thermal and nutrient stresses based on variations in spectral reflectance characteristics used for enhancing input use efficiency. Different management options like appropriate sowing time, bed planting, zero tillage, irrigation management, appropriate rate and time of fertilizer application, foliar application of $\mathrm{KNO}_{3}, \quad \mathrm{ZnSO}_{4}$ etc. can be used for management of thermal and nutrient stresses in wheat.

\section{Acknowledgement}

The authors are highly thankful to the Department of Science and Technology (DST), Govt of India, New Delhi for providing grant in the form of INSPIRE fellowship.

\section{References}

Abad, A., Michelena, A. and Lloveras, J. 2005. Effects of nitrogen supply on wheat and on soil nitrate. Agron. Sustainable Dev.,
25: 439-446.

Abedi, T., Alemzadeh, A. and Kazemeini, S. A. 2011. Wheat yield and grain protein response to nitrogen amount and timing. Australian J. Crop Sci., 5: 330-336.

Abdullah, M., Rehman, A. U., Ahmed, N. and Rasul, I. 2007. Planting time effect on grain and quality characteristics of wheat. Pakistan J. Agric. Sci. 44: 200-202.

Akram, M., Iqbal, R. M. and Jamil, M. 2014. The response of wheat (Triticum aestivum L.) to integrating effects of drought stress and nitrogen management. Bulgarian $J$. Agric. Sci. 20: 275-286.

Ali, L., Mohy-Ud-Din, Q. and Ali, M. 2003. Effect of different doses of nitrogen fertilizer on the yield of wheat. Inter. J. Agric. Bio., 5: 438-439.

Andarzian, B., Hoogenboom, G., Bannayan, M., Shiali, M. and Andarzian, B. 2015. Determining optimum sowing date of wheat using CSM-CERES-Wheat model. J. Saudi Soc. Agric. Sci., 14: 189-199.

Blackmer, T. M. and Schepers, J. S. 1995. Use of a chlorophyll meter to monitor $\mathrm{N}$ status and schedule fertigation of corn. $J$. Progressive Agric., 8: 56-60.

Blackmer, T. M., Schepers, J. S., Varvel, G. E. and Meyer, G. E. 1996. Analysis of aerial photography for nitrogen stress within corn fields. Agron. J., 88:729-733.

Broge, N. H. and Mortensen, J. V. 2002. Deriving green crop area index and canopy chlorophyll density of winter wheat from spectral reflectance data. Remote Sen. Env., 81: 45-57.

Campillo, R., Jobert, C. and Undurraga, P. 2010. Optimal nitrogen rates in winter wheat cv. Kumpa-Inia in andisols of southern Chile. Chilean J. Agric. Res., 70: 122-131.

Caviglia, O. P. and Sadras, V. O. 2001. Effect of nitrogen supply on crop conductance, water- and radiation-use efficiency of wheat. Field Crops Res., 69: 259-266.

Chunjiang, Z., Zhijie W., Jihua W. and Wenjiang, H. 2012. Relationships of leaf nitrogen concentration and canopy nitrogen density with spectral features 
parameters and narrow-band specral indices calculated from field winter wheat (Triticum aestivum L.) spectra. Inter. J. Remote Sen., 33: 3272-3291.

Cui, Z., Shi, L., Xu, J., Li, J., Zhang, F. and Chen, X. 2005. Effects of $\mathrm{N}$ fertilization on winter wheat grain yield and its crude protein content and apparent $\mathrm{N}$ losses. $J$. App. Eco. 16: 2071-2075.

Das, S. and Sarkar, A. K. 1981. Effect of postflowering foliar spray of potassium nitrate solution on grain filling and yield of rice and wheat. Indian Agric. 25: 267-273.

Daughtry, C. S. T., Walthall, C. L., Kim, M. S., de Colstoun, E. B. and McMurtrey, J. E. 2000. Estimating corn leaf chlorophyll concentration from leaf and canopy reflectance. Remote Sens. Env., 74: 229239.

Eslami, H., Mir Hadi, S. M. J. and Arabi, M. K. 2014. Effect of Planting Date on Protein content of Wheat varieties. Inter. J. Farm All. Sci., 3: 362-364.

Farooq, M., Bramley, H., Palta, J. A., Siddique, K. H. M. 2011. Heat stress in wheat during reproductive and grain-filling phases. Critical Rev. Pl. Sci., 30: 491507.

Fayed, T. B., Sarag, E. E., Hassanein, M. K. and Magdy, A. 2015. Evaluation and prediction of some wheat cultivars productivity in relation to different sowing dates under North Sinai region conditions. Ann. Agric. Sci., 60: 11-20.

Gonita, N. K. and Tiwari, K. N. 2008. Development of crop water stress index of wheat crop for scheduling using infrared thermometry. Agric. Water Manag, 95: 1144-1152.

Gitelson, A. A., Kaufman, Y. J. and Merzlyak, M. N. 1996. Use of a green channel in remote sensing of global vegetation from EOS-MODIS. Remote Sens. Env., 58: 289-298.

Guodongliu, Yuncongli, Alva, A. K., Porterfield, D. M. and Jamesdunlop. 2012. Enhancing nitrogen use efficiency of potato and cereal crops by optimizing temperature, moisture, balanced nutrients and oxygen bioavailability. $J$. Pl. Nutr., 35: 428-441.

Haslett, B. S., Reid, R. J. and Rengal, Z. 2001. Zinc mobility in wheat: Uptake and distribution of zinc applied to leaves or roots. Ann. Bot., 87: 379-386.

Hossain, A., Silva, D. J. A. T., Lozovskaya, M. V. and Zvolinsky, V. P. 2012. High temperature combined with drought affect rainfed spring wheat and barley in SouthEastern Russia: I. Phenology and growth. Saudi J. Bio. Sci., 19: 473-487.

Hozayn, M. and Monem, A. A. 2011. Alleviation of the potential impact of climate change on wheat productivity using arginine under irrigated Egyptian agriculture. In the Proceedings of International Conference on Preparing Agriculture for Climate Change, Punjab Agricultural University, Ludhiana, on February 6-8, 2011, pp 305.

Hussain, I., Ahmed, H. B., Rauf, S., Aslam, M., Aulakh, A. M. 2015. Effect of sowing time on quality attributes of wheat grain. Inter. J. Bio. Sci., 6: 1-8.

Hussain, I., Khan, M. A. and Khan, E. A. 2006. Bread wheat varieties as influenced by different nitrogen level. J. Zhejiang Univ. Sci., 7: 70-78.

IPCC. 2014. Climate change 2014: Impacts, adaptation and vulnerability. Working group II contribution to the fifth assessment report of the Intergovernmental Panel on Climate Chamge. Technical Report. Cambridge University Press, Cambridge, UK/New York, USA.

Iqbal, J., Hayat, K., Hussain, S., Ali, A. and Bakhsh, A. A. H. A. 2012. Effect of seeding rates and nitrogen level on yield and yield components of wheat (Triticum aestivum L.). Pakistan J. Nut., 11: 531536.

Jones, H. G. 2009. IR imaging of plant canopy: scaling up the remote diagnosis and quantification of plant stress to the field and beyond. In 'Abstracts of the 1st International Plant Phenomics Symposium: from Gene to Formand 
Function'. Available at http://www.plantphenomics.org.au/IPPSO 9/abstracts [Verified 22 September 2009]

Joshi, A. K., Mishra. B., Chatrath, R., Ortiz Ferrara, G. and Singh, R. P. 2007. Wheat improvement in India: Present status, emerging challenges and future prospects. Euphytica 157: 457-464.

Kajla, M., Yadav, V. K., Chhokar, R. S. and Sharma, R. K. 2015. Management practices to mitigate the impact of high temperature on wheat. J. Wheat Res., 7: 1-12.

Kaur, A., Pannu, R. K. and Buttar, G. S. 2010. Impact of nitrogen application on the performance of wheat (Triticum aestivum) and nitrogen use efficiency under different dates of sowing. Indian $J$. Agron., 55: 40-45.

Kaur, R., Singh, B., Singh, M. and Thind, S. K. 2015. Hyperspectral indices, correlation and regression models for estimating growth parameters of wheat genotypes. $J$. Indian Soc. Remote Sen., (Online) http://www.researchgate.net/publication/ 272426933.

Khalilzadeh, G., Eivazi, A. and Mozaffari, J. 2011. Effect of nitrogen on grain yield, grain protein and agronomic nitrogen use efficiency in winter wheat (Triticum aestivum L.) cultivars. Inter. J. Agric. Crop Sci., 3: 34-42.

Kumar, B., Dhir, S., Vyas, A. K. and Paramesh, V. 2015. Impact of irrigation schedules and nutrient management on growth, yield and root traits of wheat (Triticum aestivum) varieties. Indian J. Agron., 60: 87-91.

Kumar, S., Bangarwa, A. S., Singh, D. P. and Phogat, S. B. 1998. Drymatter accumulation in dwarf wheat varieties under different nitrogen level and sowing dates. J. Res., 28: 151-157.

Kumari, K., Sharma, M. R. K. and Balloli, S. S. 2000. Effect of late application of nitrogen on yield and protein content of wheat. Ann. Agric. Res., 21: 288-291.

Latiri-Souki, K., Nortcliff, S. and Lawlor, D. W. 1998. Nitrogen fertilizer can increase dry matter, grain production and radiation and water use efficiency for durum wheat under semi-arid conditions. European J. Agron., 9: 21-34.

Li, L., Hong, J. P., Wang, H. T., Xiu, Y. H. and Zhang, L. 2013. Effects of watering and nitrogen fertilization on the growth, grain yield, and water- and nitrogen use efficiency of winter wheat. J. App. Eco., 24: 1367-1373.

Lopes, M. and Reynolds, M. 2012. Stay-green in spring wheat can be determined by spectral reflectance measurements (normalized difference vegetation index) independently from phenology. J. Exp. Bot., 63: 3789-3798.

Mahey, R. K., Singh, R., Sidhu, S. S. and Narang, R. S. 1991. The use of remote sensing to assess the effects of water stress on wheat. Env. Agric., 27: 423-429.

Mandic, V., Krnjajai, V., Tomic, Z., Bijelici, Z., Simic, A., Muslic, D. R. and Gogic, M. 2015. Nitrogen fertilizer influence on wheat yield and use efficiency under different environmental conditions. Chilean J. Agric. Res., 75: 92-97.

Maqsood, M., Akbar, M., Mahmood, M. T. and Wajih, A. 2000. Yield and quality response of wheat to different nitrogen doses in rice-wheat cropping system. Inter. J. Agric. Bio., 2: 107-108.

Mauriya, A. K., Maurya, D. C., Maurya, V. K. and Verma, R. K. 2015. Effect of zinc application methods on yield attributes, yield and nutrient uptake in wheat (Triticum aestivum) varieties under sodic soil. Indian J. Agron., 60: 82-86.

Meena, R. K., Parihar, S. S., Singh, M. and Khanna, M. 2015. Influence of date of sowing and irrigation regimes on crop growth and yield of wheat (Triticum aestivum) and its relationship with temperature in semi-arid region. Indian J. Agron., 60: 92-98.

Mohanty, M., Sinha, N. K., Hati, K. M., Reddy, K. S. and Chaudhary, R. S. 2015. Elevated temperature and carbon dioxide concentration effects on wheat productivity in Madhya Pradesh: a 
simulation study. J. Agromet., 17: 185189.

Moraes, L. B. D. D., Freo, J. D., Biduski, B., Elias, M. C. and Gutkoski, L. C. 2013. Effects of rate, time and splitting of nitrogen fertilization on the technological quality of wheat. J. Food Sci. Eng., 3: 918.

Mukherjee, D. 2012. Effect of different sowing dates on growth and yield of wheat (Triticum aestivum L.) cultivars under mid hill situation of West Bengal. Indian J. Agron., 57:152 -156.

Munsif, F., Arif, M., Ali, K., Jan, M. T. and Khan, M. J. 2015. Influence of planting dates on grain quality of different wheat cultivars in dual purpose system. Inter. J. Agric. Bio., 17: 945-952.

Nishio, Z., Lto, M., Tabiki, T., Nagasawa, K., Yamauchi, H., Hirota, T. 2013. Influence of higher growing season temperatures on yield components of winter wheat (Triticum aestivum L.). Crop Sci., 53: 621-628.

Ooro, P. A., Malinga, J. N., Tanner, D. G. and Payne, T. S. 2011. Implication of rate and time of nitrogen application on wheat (Triticum aestivum L.) yield and quality in Kenya. J. Animal Pl. Sci. 9: 1141-1146.

Perry, M. L. and Swaminathan, M. S. 1992. Climate change on food production", Mintzer (ed) Confronting climate changerisk, implications and responses. Cambridge University press. pp 113-25.

Prabhjyot-Kaur. And Hundal, S. S. 2010. Global climate change vis-à-vis crop productivity. In pp. 413-431 "Natural and anthropogenic disasters - Vulnerability, preparedness and mitigation" (Editor Jha M K), Capital Publishing Company, New Delhi and Springer, The Netherlands.

Rahman, M. A., Chikushi, J., Yoshida, S. and Karim, A. J. M. S. 2009. Growth and yield components of wheat genotypes exposed to high temperature stress under control environment. Bangladesh $J$. Agric. Res. 34: 361-372.

Reddy, K. R. and Hodges, H. F. 2000. Climate change and global crop productivity",
(Reddy K R and Hodges H F Eds.) CAB International Walling ford U K. pp 1-5.

Reddy, S. R. 2006. Agronomy of field crops. Pp 143-88. Kalyani Publishers.

Refay, Y. A. 2011. Yield and yield component parameters of bread wheat genotypes as affected by sowing dates. Middle East J. Sci. Res., 7: 484-489.

Sarkar, A. K. and Tripathy, S. K. 1994. Effect of nitrate and its counter ions applied as post flowering foliar spray on grain filling and yield of wheat. Indian Agric., 38: 6973.

Scharf, P. C., Alley, M. M. and Lei, Y. Z. 1993. Spring Nitrogen on winter wheat: I. Farmer-validation of tissue test based rate recommendations. Agron Journal 85: 1181-1186.

Serrano, L., Filella, I. and Penuelas, J. 2000. "Remote sensing of biomass and yield of winter wheat under different nitrogen supplies", Crop Science 40: 723-731.

Shahramlack, Ghooshch, F. and Tohidimogaddam, H. 2011. "Effect of zinc spraying on yield and yield components of wheat under drought stress conditions", In the Proceedings of International Conference on Preparing Agriculture for Climate Change, Punjab Agricultural University, Ludhiana, on February 6-8, 2011, p 307.

Sharma, K. D., Pannu, R. K. and Behl, R. K. 2007. Effect of early and terminal heat stress on biomass partitioning, chlorophyll stability and yield of different wheat genotypes. Proc: The international conference on sustainable crop production in stress environment: Management and genetic options. Pp 187-94.Agrobios (International), Jodhpur.

Shekoofa, A. and Emami, Y. 2008. Effects of Nitrogen Fertilization and Plant Growth Regulators (PGRs) on Yield of Wheat (Triticum aestivum L.) cv. Shiraz. J. Agric. Sci. Tech., 10: 101-108.

Sial, M. A., Arain, M. A., Khanzada, S., Naqvi, M. H., Dahot, U. and Nizamani, N. A. 2005. Yield and quality parameters of wheat genotypes as affected by sowing 
dates and high temperature stress. Pakistan J. Bot., 37: 575-584.

Singh, A., Singh, D., Kang, J. S. and Aggarwal, N. 2011. Management practices to mitigate the impact of high temperature on wheat: A review. IIOAB J., 2: 11-22.

Singh, P., Bhowmik, J. and Chaudhury, B. K. 2006. Effect of temperature on yield and yield components of fourteen wheat (Triticum eastivum L.) genotypes. Env. Eco, 24:550-554.

Singh, V., Ali, J., Seema, Kumar, A. and Chauhan, T. M. 2015. Productivity, nutrient uptake and economics of wheat (Triticum aestivum) under potassium and zinc nutrition. Indian J. Agron., 60: 426430.

Sripada, R. P., Farrer, D. C., Weisz, R., Heiniger, R. W. and White, J. F. 2007. Aerial color infrared photography to optimize in-season nitrogen fertilizer recommendations in winter wheat. Agron J., 99: 1424-1435.

Srivastava, N., Singh, D., Shukla, A., Guru, S. K., Singh, M., Rana, D. S. 2012. Effect of high temperature stress at post anthesis stage on Photo-system II, senescence, yield and yield attributes of wheat genotypes. Indian J. Pl. Physio., 17: 158-165.

Warraich, E. A., Basra, S. M. A., Ahmed, N., Ahmed, R. and Aftab, M. 2002. Effect of Nitrogen on Grain Quality and Vigour in Wheat (Triticum aestivum L.). Inter. J. Agric. Bio., 4: 517-520.

Zacharias, M., Singh, S. D., Kumar, S. N., Aggarwal, P. K. and Harit, R. C. 2010. Impact of elevated temperature at different phenological stages on the growth and yield of wheat and rice. Indian J. Pl. Physio., 15: 315-357.

Zhang, X., Cai, J., Wollenweber, B., Liu, F., Dai, T., Cao, W., Jiang, D. 2013. Multiple heat and drought events affect grain yield and accumulations of high molecular weight glutenin subunits and glutenin macropolymers in wheat. J. Cereal Sci., 57: 134-140.

\section{How to cite this article:}

Sukhjeet Kaur, Som Pal Singh and Kingra, P.K. 2017. Detection and Management of Abiotic Stresses in Wheat Using Remote Sensing Techniques. Int.J.Curr.Microbiol.App.Sci. 6(8): 616628. doi: https://doi.org/10.20546/ijcmas.2017.608.079 